\title{
Therapeutic Role of Phytochemicals in the Prevention of Oral Potentially Malignant Disorders and Oral Cancer - A Review
}

\author{
Ravleen Nagi ${ }^{1}$, N. Rakesh ${ }^{2}$, Sujatha S. Reddy ${ }^{3}$, Aravinda Konidena ${ }^{4}$, Ramanpal Singh Makkad ${ }^{5}$, Tarun Vyas ${ }^{6}$
}

${ }^{1,4}$ Department of Oral Medicine \& Radiology, Swami Devi Dyal Hospital and Dental College, Barwala, Panchkula, Haryana, India. ${ }^{2,3}$ Department of Oral Medicine \& Radiology, M.S. Ramaiah University of Applied Sciences, Bangalore,

Karnataka, India. ${ }^{5}$ Department of Oral Medicine \& Radiology, New Horizon Dental College and Research Institute, Bilaspur, Chhattisgarh, India. ${ }^{6}$ Department of Oral Medicine \& Radiology, RR Dental College, Udaipur Rajasthan, India.

\section{ABSTRACT}

\section{BACKGROUND}

Medicinal plants and their extracts have been found to possess potent antiinflammatory, antioxidant and anti-cancer properties that slow down the cellular proliferation and malignant transformation rate of orally potential malignant disorders such as oral leukoplakia, oral submucous fibrosis and oral lichen planus. They are a potential source of antioxidants such as vitamin A, E, and C that neutralize the free radicals produced in various oral mucosal lesions thereby preventing the mucosal damage. They have been found to modulate cellular signalling pathways and, this activation influences the cellular defence mechanisms that protect the normal cells against reactive oxygen species or reactive metabolites and induces apoptotic death of cancerous cells, thus chemoprevention ensues to prevent, reverse or delay carcinogenesis. They have been studied to enhance tumour cell killing and inhibition of metastasis by increasing number of immunocompetent cells such as macrophages, cytotoxic T lymphocytes, natural killer cells and by recruitment of antibodies at the tumour site. Now a days, natural herbs or phytochemicals are gaining attention due to side effects and increased antimicrobial resistance that often occur with prolonged use of chemotherapeutic agents. Therapeutic effect of phytochemicals in oral PMDs is very promising as they prevent the progression of dysplasia from mild to severe. Literature has revealed significant reduction in burning sensation, difficulty in swallowing and speech, and pain associated with the oral mucosal lesion. However, more research should be conducted in future to establish their use as an adjunctive therapy in oral potentially malignant disorders. By this review, an attempt has been made to highlight therapeutic potential of diverse herbs such as aloe vera, tulsi, neem, curcumin, lycopene, green and black tea, peppermint etc. in the reduction of clinical symptoms of burning sensation and pain associated with the oral mucosal lesions, and discusses their indispensable role in prevention of oral cancer.

\section{KEY WORDS}

Antioxidants, Chemoprevention, Phytochemicals, Oral Cancer
Corresponding Author: Ravleen Nagi, Oral Medicine \& Radiology, Swami Devi Dyal Hospital and Dental College, Barwala, Panchkula, Haryana, India.

E-mail: ravleennagi@yahoo.in

DOI: $10.14260 / j e m d s / 2021 / 246$

How to Cite This Article:

Nagi R, Rakesh N, Reddy SS, et al. Therapeutic role of phytochemicals in the prevention of oral potentially malignant disorders and oral cancer - a review. J Evolution Med Dent Sci 2021;10(16):11561165, DOI: 10.14260/jemds/2021/246

Submission 25-10-2020,

Peer Review 17-02-2021,

Acceptance 22-02-2021,

Published 19-04-2021.

Copyright (c) 2021 Ravleen Nagi et al. This is an open access article distributed under Creative Commons Attribution License [Attribution 4.0 International (CC BY 4.0)] 


\section{BACKGROUND}

Oral mucosal lesions (OMLs) have been defined as an abnormal change in oral mucosa, and diverse clinical presentations of OMLs are red and white patches, ulcerations, swellings or growth, pigmentations or as normal variants are commonly encountered by the oral physicians in their daily clinical practice. ${ }^{1}$ They can occur as solitary isolated lesions or in association with dermatological diseases, and present a diagnostic challenge to clinicians. Oral potentially malignant disorders (PMDs) such as leukoplakia, erythroplakia, etc present as white or red patches or as chronic non healing ulcer and require early diagnosis, prompt treatment to prevent malignant transformation. OML may be asymptomatic or symptomatic with pain / discomfort that may interfere with mastication or swallowing, besides this burning sensation to spicy foods, taste alterations, xerostomia, etc. are some common symptoms that affect the daily functional activities of patient. Therefore, clinicians should have adequate knowledge about the likely differential diagnosis of similar appearing lesions and emerging treatment options for their proper diagnosis and management. ${ }^{2}$

Literature revealed that most of the chemotherapeutic agents have significant adverse effects and cause antimicrobial resistance on prolonged use.3,4 Due to potential benefits of diverse herbs such as aloe vera, curcumin, tulsi, lycopene, green tea etc. researchers are moving towards botanical based medicines or plant derived derivatives, known as phytochemicals.4,5,6 Clinicals trials have shown that therapeutic effect of phytochemicals in oral PMDs is very promising as they prevent the progression of dysplasia from mild to severe. $1,4,5$

\section{OXIDATIVE STRESS AND ORAL POTENTIALLY MALIGNANT DISORDERS}

Several studies elucidating the association of oxidative stress as a contributing etiological factor in wide variety of oral diseases has been documented in the literature.7,8 Oxidative stress potentiates the release of highly reactive free radicals or reactive oxygen species (ROS) such as superoxide $\left(\mathrm{O}_{2}\right)$, hydroxyl $(\mathrm{OH})$ and nitric oxide (NO). ${ }^{7}$ Cigarette smoke produces ROS mainly in form NO, and chronic alcohol consumption leads to production of ROS, and DNA adducts which are established risk factors for oral cancer. ${ }^{8}$ Oxidative stress damages the cellular protein by increasing its cross linkage, and fragmentation and affects DNA repair mechanisms, thereby resulting in increased DNA mutations [Figure 1].8,9

\section{ROLE OF PHYTOCHEMICALS IN FIGHTING OXIDATIVE STRESS}

Studies have shown that phytochemical compounds present in natural herbs such as beta-carotene, lycopene, neem, aloe vera, tulsi, curcumin, etc. and their extracts have wide range of biological activity that include antibacterial, antiinflammatory, anti-oxidant, anti-proliferative properties and suggested them to play key role in chemoprevention. ${ }^{10,11}$ Upon entry into cells, phytochemicals are able to scavenge the free radicals immediately, and modulate cellular signalling pathways. Consequently, this activation influences the cellular defence mechanisms that protects the normal cells against ROS or reactive metabolites and induces apoptotic death of cancerous cells, thus chemoprevention ensues to prevent, reverse or delay carcinogenesis. Table 1 illustrates molecular targets of phytochemicals.

\section{PHYTOCHEMICALS AND THEIR MECHANISM OF ACTION}

\section{Lycopene}

Lycopene belongs to genus lycopersicum, is a bright red carotenoid pigment extracted from red fruits and vegetables chiefly tomato, red carrots, red bell peppers, watermelons, and papayas. ${ }^{11}$

\begin{tabular}{|c|c|c|}
\hline Phytochemical Action & Increases & Decreases \\
\hline Cell proliferation & $\begin{array}{c}\text { P53, p16, p27 } \\
\text { cyclins D1, E, B1 }\end{array}$ & $\begin{array}{c}\text { CDK - 1, 2, } 4 \\
\text { CDC - } 2\end{array}$ \\
\hline Apoptosis & $\begin{array}{c}\text { Bax, cyt C, caspase } \\
\text { activation, PARP cleavage }\end{array}$ & $\begin{array}{c}\text { Bcl 2, Bcl-xL, survivin, TRAF } \\
1\end{array}$ \\
\hline Transcription factors & Nrf 2 & $\begin{array}{l}\text { NFKB, AP-1, STAT, MPAK, } \\
\text { PI3K, Akt, } \beta \text { catenin }\end{array}$ \\
\hline $\begin{array}{l}\text { Antioxidant-oxidative } \\
\text { system }\end{array}$ & SOD, GSH & $\begin{array}{c}\mathrm{O}_{2}-\mathrm{OH}^{-}, \mathrm{NO}, \mathrm{COX} 2, \mathrm{LOX} \\
\text { NOS, }\end{array}$ \\
\hline Tumour angiogenesis & $\cdots$ & $\begin{array}{l}\text { VEGF, EGF, TGF } \alpha \text {, PDGF, } \\
\text { VEGFR }\end{array}$ \\
\hline Tumour invasion & MMP & ICAM, VCAM, ELAM, TIMP \\
\hline
\end{tabular}

\section{Chemical Structure and Composition}

It is a carotenoid, acyclic, lacks $\beta$-ionone ring; structure needed to form vitamin A therefore has no pro vitamin A activity that distinguishes its biochemistry from carotenes, $\alpha$ and $\beta$ carotene. ${ }^{11}$ Lycopene extract is produced from tomatoes with high concentration of lycopene approximately 150 - $250 \mathrm{mg} /$ $\mathrm{kg}$. Lycopene is a 40-carbon acyclic carotenoid containing 11 conjugated double bonds, contributing to its red colour. It exists as all trans isomer in natural form, is an unsaturated acyclic hydrocarbon with chemical formula C40H56 and molecular mass of 536.85 atomic mass unit (amu). ${ }^{11,12}$

\section{Mechanism of Action}

It has been reported to be effective quencher of singlet oxygen $\left(\mathrm{O}_{2}\right)$, and free radicals such as hydroxyl, $\mathrm{OH}$ and peroxy radicals, and has been hypothesized to prevent carcinogenesis by inhibition of proliferation of killer B-1 (KB-1) cells, by upregulation of gap junction protein, connexin 43 expression, and enhances gap junctional communication. Its other beneficial effects are due to their ability to arrest cell cycle progression from G0 / G1 to S phase, interference with growth factor stimulation, regulation of transcription, increase of p53 protein levels and induction of phase II enzymes (Figure 2). ${ }^{12,}$ 13,14

\section{Dosage and Clinical Trials}

Regarding the dosage of lycopene, the daily intake of lycopene has been suggested to be $3.7 \mathrm{mg}$. Studies have shown that, lycopene when given in a dosage of $4-8 \mathrm{mg} /$ day orally for three months in case of oral leukoplakia, and $16 \mathrm{mg} /$ day for oral submucous fibrosis could prevent the risk of malignant 
transformation. These studies have emphasized that daily oral dose of $8 \mathrm{mg}$ is more efficacious than $4 \mathrm{mg}$ a day in clinical improvement of oral leukoplakia, and has been found to prevent the oxidative damage in atrophic and erosive OLP.11,13 Gowda et al. observed the clinical improvement of oral submucous fibrosis patients after treatment with lycopene, $2000 \mu \mathrm{g}$, twice daily, for three months, with no significant toxicity. ${ }^{14}$ Kushwaha et al. found complete remission of atrophic and erosive oral lichen planus (OLP) after 8 weeks of treatment of lycopene. They concluded that lycopene is an effective therapeutic option for reversal of dysplastic changes in oral potentially malignant disorders (OPMDs) due to its antioxidant and anti-inflammatory activity. ${ }^{15}$

\section{Brand Available}

Lycopene is available in the market under different brand names as Lycored, Lynet, Lyconex (gennext), Lycobin etc.

\section{Beta-Carotene}

Beta carotene ( $\beta$ carotene) is a precursor to vitamin $A$ and dark green, orange and yellowish fruits and vegetables are rich source of $\beta$ carotene. 16

\section{Chemical Structure and Composition}

$\beta$ carotene belongs to the family of carotenoids which are terpenoids / isoprenoids. Basic structure is made up of 8 isoprene units, joined end to end to form an unconjugated chain and have $\beta$ rings at both the ends, long conjugated chain imparts orange colour to $\beta$ carotene. ${ }^{16,17}$

\section{Mechanism of Action}

Carotenoids are scavenger of free radicals, they produce genetic and molecular responses such as overexpression of p53, reduction in neovascularization of tumour cells and induction of apoptosis. Their other actions are i) immunomodulation, stimulation of cell mediated immune response by increasing the activity of $\mathrm{T}$ lymphocytes; helper $\mathrm{CD}_{4}$ lymphocytes, monocytes, cells with interleukin 2 (IL 2), tumour necrosis factor alpha (TNF $\alpha$ ), and natural killer (NK) cells ii) inhibition of mutagenesis, and iii) inhibition of cancer cell growth, iv) reduces progression of dysplasia in oral PMDs, and $v$ ) reduce the expression of growth factors and immune regulatory factors (Figure 3).4,16,17

\section{Dosage}

Physicians usually recommend $\beta$ carotene from the food rather than as dietary supplements, limited trials have been conducted to establish the minimum level of $\beta$ carotene required for the human health. As a dietary supplement, it is available in form of capsules and chewable tablets; 6 to $15 \mathrm{mg}$ of $\beta$ carotene per day and 3 to $6 \mathrm{mg}$ of $\beta$ carotene per day has been recommended for adults and children, respectively. ${ }^{16}$

\section{Brand Available}

It is marketed under brand names: Lumitene, A-Caro-25, Solatene, Centrum, Singles $\beta$ carotene in form of capsules or chewable tablets.

\section{Clinical Trials}

Studies have suggested that serum carotene levels are decreased in oral PMDs and $30 \mathrm{mg} /$ day $\beta$ carotene capsules twice daily for 12 weeks result in increase in mouth opening, reduction in burning sensation, and thickness of collagen bundles in oral submucous fibrosis (OSMF) patients. ${ }^{16,17}$ Randomised controlled trials reported that clinical improvement of oral PMDs with $\beta$ carotene ranged from 14.8 $\%$ to $71 \%$ with no significant side effects, only yellow discoloration of skin was seen in few patients. ${ }^{16}$ Garewal et al. ${ }^{17}$ showed a complete and partial response rate of $71 \%$ in oral leukoplakia patients treated with a regimen; $\beta$ carotene $30 \mathrm{mg}$ / day for 3 months, followed by additional 3 months for responding patients, with no observable side effects.

\section{Curcumin}

Curcuma longa $\mathrm{L}$. well known as turmeric or curcumin isolated from the root rhizomes of the plant Zingiberaceae, is one of the widely used herb in Unani, Ayurveda, Siddha and Chinese medicinal systems for the management of various ailments such as dermatological diseases, infections and stress. ${ }^{18}$

\section{Chemical Structure and Composition}

Curcumin is the main chemical constituent of turmeric with formula C21H2006 and molecular weight $368.38 \mathrm{amu}$. Curcuminoids such as curcumin, desmethoxycurcumin, bisdemethoxycurcumin are natural polyphenols and are the major phytochemicals known for their antioxidant, antiinflammatory and anticancer potential.18,19

\section{Mechanism of Action}

Its therapeutic effect in oral PMDs is explained by its potential to affect biological pathways that promote carcinogenesis. It inhibits the activity of nuclear factor $-\kappa B(N F-\kappa B)$ transcription factor and genes involved in cellular proliferation such as cyclooxygenase (COX-2), TNF- $\alpha$, cyclin D1, ICAM-1, c-myc, Bcl2, matrix metallo-proteinases (MMP-9), inducible nitric oxide synthase (iNOS), and IL-6, IL-8. Moreover, curcumin acts at different stages of carcinogenesis process, causes cell cycle arrest, promotes apoptosis by up regulation of p16 and p53, and activation of p53 decreases expression of anti-apoptotic protein bcl 2. It inhibits tumour angiogenesis and metastasis by its inhibitory effect on VEGF, ICAM 1, MMP-9 and COX-2, acts as a scavenger of ROS and reactive nitrogen species generated by the oxidative stress mechanisms in PMDs and results in dose dependent reduction in cell adhesion molecules especially E cadherin involved in tumour growth.4,19 The anticancer effects of curcumin are mainly attributed by alteration of multiple cellular signalling pathways involved in cellular growth, apoptosis, invasion and metastasis which eventually result in activation of caspase 3 and concomitant PARP cleavage, and induces caspase dependent apoptotic pathway (Figure 5).20

\section{Dosage}

Turmeric is available in both topical and oral formulation. Most common therapeutic regimen is 400 - $600 \mathrm{mg}$ of turmeric capsules thrice a day for 8 weeks. It can be used as $5 \%$ curcumin oral paste thrice a day for four weeks for symptomatic relief in oral lichen planus and oral submucous fibrosis lesions. ${ }^{18,19}$

\section{Brands Available}

Tablets Turmix (300 mg curcumin and $5 \mathrm{mg}$ piperine), $50 \mathrm{~g}$ curcumin cure next oral gel. 


\section{Clinical Trials}

Studies have used turmeric in various formulations as capsules, oil or $1 \%$ curcumin mucoadhesive gel and found it as an effective agent in reducing burning sensation in oral PMDs due to its anti-inflammatory action, Nigam et al. ${ }^{19}$ found significant reduction in visual analog scale (VAS) score from 6.91 to 3.98. In another study on OLP patients, significant improvement in burning sensation, ulceration and striae was noted after local application of turmeric extract twice daily for 3 months, Srivastava et al. ${ }^{21}$ in his study observed significant improvement in burning sensation and mouth opening in OSMF patients $(\mathrm{P}<0.01)$. Due to lack of systemic toxicity and potent anti-tumour properties it could be used as an adjuvant therapy to treat PMDs resistant to currently available therapies. Studies have revealed that low solubility, high rate of metabolism, and low bioavailability of curcumin has become a challenge to effectively treat oral PMDs. To overcome this, nano formulation of curcumin has been introduced that enhances the bioavailability of curcumin, increases efficacy of topical corticosteroid triamcinolone acetonide, and reduces the need of prolonged administration of corticosteroids for the treatment of precancerous lesions. ${ }^{22}$

\section{Green Tea}

Green tea and black tea made from young leaves and leaf buds of tea plant Camellia sinensis have been studied for their chemo preventive potential and green tea has shown greater efficacy against multiple cancers. ${ }^{23}$

\section{Chemical Structure and Composition}

It contains four major polyphenols: epicatechin (EC), epigallocatechin (EGC), epicatechin-3-gallate (ECG), and epigallocatechin 3-gallate (EGCG), comprising 1 - $3 \%$, 3 - $6 \%$, $3-6 \%$ and $7-13 \%$ respectively of the fresh green tea leaf dry weight. 23,24

\section{Mechanism of Action}

Green tea exerts its action in different ways (Figure 4):23-25

1. Its antioxidant potential is attributed to neutralisation of free radicals by the hydroxyl groups,

2. EGCG is most active catechin, it inhibits tumour proliferation, induces apoptosis, arrests cells in G0 - G1 phase, down regulates cyclin D1 levels, increases p14 and p16 protein levels thus stabilize p53, and blocks angiogenesis by inhibition of vascular endothelial growth factor (VEGF) secretion by tumour cells.

3. EGCG acts on proteins and genes involved in development and progression of head and neck cancers, that include NF-ḱB, EGFR, STAT3, Activator protein 1 (AP-1), Mitogen activated protein kinases (MAPK), TNF.

\section{Dosage}

Ingestion of 3 - 5 cups / day (up to $1200 \mathrm{ml}$ / day) provides minimum of $250 \mathrm{mg} /$ day catechins. For oral lesions, oral intake of $3 \mathrm{~g}$ of green tea has been found to be adequate.

\section{Brands Available}

Various green tea brands are available in market: Tetley green tea, Tazo green tea, twinning jasmine green tea, etc., and chewing gums containing green tea extract $120 \mathrm{mg}$; e.g. Xyloburst chewing gum (100 ct) are also available.

\section{Clinical Trials}

Hsu et al. ${ }^{25}$ showed that EGCG was able to effectively inhibit the growth and invasion of tumour cells. For PMDs, oral green tea extract dose of $1 \mathrm{gm} / \mathrm{cm}^{2}$ thrice daily for at least 6 months was found effective. ${ }^{26}$ Schwartz et al. ${ }^{27}$ performed a pilot study in which green tea extract (2000 - $2500 \mathrm{mg} /$ day) given to smokers for four weeks showed reduction of smoking induced DNA damage and inhibition of tumour cell growth. Besides this, overexpression of HER-2 (neu / erbB2) has been found to contribute towards progression of oral cancer. ${ }^{28,29}$

\section{Aloe Vera (Aloe barbadensis)}

Aloe vera is jelly like fleshy plant of the genus aloe, the inside of which contains liquid jelly that has soothing effect and is widely accepted species for medicinal and pharmaceutical purpose in many countries. 30

\section{Chemical Structure and Composition}

Aloe leaf has two major parts; i) the outer green rind including vascular bundles, and ii) the inner colourless parenchyma or pulp containing aloe gel. Aloe vera pulp is made up of three structural components: cell wall, the degenerated organelles and the viscous mucinous liquid gel within the cell. Aloe gel comprises of $99.5 \%$ water and remaining $0.5-1 \%$ of water soluble and fat-soluble vitamins, salicylic acid, minerals, sugars, enzymes, lignin, saponins, and amino acids. ${ }^{30-32}$

\section{Mechanism of Action}

The primary therapeutic effect of aloe vera is attributed to the polysaccharides contained in the gel of the leaves. It has excellent wound healing properties, some researchers have hypothesized that it increases both collagen synthesis and its cross linkage at the site of wound, which may be due to presence of acemannan, component of aloe vera composed of long chain of acetylated mannose, a muco-polysaccharide. Its macrophage activating potential stimulates the release of fibrogenic cytokines and its direct binding to growth factors stimulates the granulation tissue. Its anti-inflammatory effect is due to inhibition of COX, thereby reduces production of PGE 2, Lupeol is the most potent anti-inflammatory sterol of aloe vera that reduces inflammation in dose dependent manner. Aloe vera emodin, an anthraquinone, has the ability to inhibit apoptosis, growth and proliferation of cancerous cells (Figure 6)

\section{Dosage}

Aloe vera is available in form of gels, toothpastes, capsules and juice. It is recommended to take $200-300 \mathrm{mg}$ of capsules per day, about 2 - 3 tablespoons ( $50 \mathrm{ml})$ of aloe vera juice per day, and $0.5 \%$ aloe vera oral gel. 29,30

\section{Clinical Trials}

Sudarshan et al. ${ }^{32}$ found statistically significant reduction in burning sensation $(\mathrm{P}=0.008)$, improvement in mouth opening $(\mathrm{P}=0.02)$, and cheek flexibility $(\mathrm{P}=0.01)$ in OSMF patients. Ali et al 33 found weak evidence of aloe vera in management of symptomatic OLP patients, they concluded that aloe vera is more efficient and has comparable effect to triamcinolone acetonide. 


\begin{tabular}{|c|c|c|}
\hline $\begin{array}{l}\text { Naturally Occurring } \\
\text { Phytochemical }\end{array}$ & Plant Source & Preventive Actions \\
\hline Apigenin & Moringa peregrina, chamomile & Induces apoptosis \\
\hline Colchicine* & Colchicum autumnale & Anti-mitotic \\
\hline Curcumin & Curcuma longa & $\begin{array}{l}\text { Induces apoptosis in cancerous cells } \\
\text { Inhibits growth of tumour cells by reduction of COX 2, MMP 2, and EGFR expression }\end{array}$ \\
\hline Cyanidin * & Berries, plums, red cabbage and red onions & Inhibits tumour cell growth, $\mathrm{COX} 2$ gene expression, and promotes the activation of $\mathrm{AP}-1$ and $\mathrm{NF}-\mathrm{kB}$ \\
\hline 3, 3' - Diindolylmethane (DIM) & $\begin{array}{l}\text { Brassica sps. that includes vegetables such } \\
\text { as broccoli, cauliflower, and collard greens }\end{array}$ & $\begin{array}{l}\text { DIM modulates key CYP enzymes } \\
\text { Inhibits angiogenesis, metastasis, and invasion of cancer cells }\end{array}$ \\
\hline Epigallocatechin gallate (ECGC) & Green tea & Inhibits apoptosis and reduces expression of EGFR \\
\hline Etoposide* & Podophyllum peltatum & Mitotic block \\
\hline Genistein * & $\begin{array}{c}\text { Vicia faba } \\
\text { Soya beans } \\
\text { Flemingia vestita (coffee) }\end{array}$ & Inhibits angiogenesis and tumour cell proliferation \\
\hline Gingerol* & Zingiber officinale (ginger) & Decreases iNOS and TNF-alpha expression and induces apoptosis \\
\hline Lycopene & $\begin{array}{l}\text { Tomato, red carrot, watermelon and red } \\
\text { papaya }\end{array}$ & $\begin{array}{c}\text { Inhibits tumour cell proliferation, upregulates gap junction protein, i.e. connexin } 43 \text { expression, and } \\
\text { enhances gap junctional communication. }\end{array}$ \\
\hline Phenyl isothiocyanates (PEITC)* & Broccoli, cabbage (cruciferous vegetables) & $\begin{array}{c}\text { Induces cell cycle arrest at G2 / M phase, Akt inactivation, and downregulates ERK } 1 \text { / } 2 \text { and MEK } \\
\text { phosphorylation }\end{array}$ \\
\hline Resveratrol * & Grapes and peanuts & Anti-inflammatory action, inhibits COX 2, MMP expression, tumour invasion and metastasis \\
\hline Vitamin D3* & Mushroom & Vitamin D receptors (VDR) \\
\hline Vitamin E (tocopherol)* & Sunflower oil & $\begin{array}{l}\text { Inhibit NF-kB, STAT- } 3 \text { and COX } 2 \\
\text { Supresses cell proliferation, activity of NF kB, and inhibits activation of ERK MAP kinase }\end{array}$ \\
\hline Vindesine* & Vinca roseus & Mitotic block \\
\hline Vinorelbine* & Vinca roseus & Mitotic block \\
\hline \multicolumn{3}{|c|}{ Table 2. Phytochemicals from Medicinal Herbs, Their Sources, and Anticancer Actions } \\
\hline
\end{tabular}

\begin{tabular}{|c|c|c|c|}
\hline Author (Year) & Intervention & Herbal Agent Used & Outcome \\
\hline $\begin{array}{l}\text { Garewal et al. } \\
\quad(1990)^{17}\end{array}$ & $\begin{array}{c}\text { To evaluate response of oral leukoplakia to } \beta \\
\text { carotene }\end{array}$ & $\begin{array}{c}\text { B carotene } 30 \mathrm{mg} / \text { day for } 3 \text { months to } 24 \text { oral } \\
\text { leukoplakia patients }\end{array}$ & $71 \%$ response rate observed. \\
\hline $\begin{array}{l}\text { Singh et al. } \\
(2004)^{13}\end{array}$ & $\begin{array}{c}\text { Efficacy of lycopene in the treatment of oral } \\
\text { leukoplakia }\end{array}$ & $\begin{array}{c}20 \text { patient's lycopene } 8 \mathrm{mg} / \text { day, } 20 \text { patients lycopene } 4 \\
\text { mg / day }\end{array}$ & $\begin{array}{c}\text { Mean response of } 80 \%, 66.25 \% \text { and } 12.5 \% \text { was seen with } 8 \\
\text { mg, } 4 \text { mg lycopene and placebo, respectively }\end{array}$ \\
\hline $\begin{array}{l}\text { Schwartz et al. } \\
\quad(2005)^{27}\end{array}$ & $\begin{array}{l}\text { Molecular and cellular effects of green tea on } \\
\text { oral cells of smokers }\end{array}$ & $\begin{array}{l}\text { Green tea total extract }(2000-2500 \mathrm{mg} / \text { day }) \text { was } \\
\text { given to smokers for four weeks }\end{array}$ & $\begin{array}{l}\text { Cell growth was reduced, and markers of apoptosis were } \\
\text { upregulated. }\end{array}$ \\
\hline $\begin{array}{l}\text { Sudarshan et al. } \\
\qquad \text { (2012) }\end{array}$ & $\begin{array}{l}\text { To compare the efficacy of Aloe vera with } \\
\text { antioxidants in the treatment for OSMF. }\end{array}$ & $\begin{array}{l}\text { Group A: Topical application of } 5 \mathrm{mg} \text { of Aloe vera gel } \\
\text { three times daily for } 3 \text { months } \\
\text { Group B: Antioxidant capsules twice daily for } 3 \text { months }\end{array}$ & $\begin{array}{l}\text { Aloe vera showed a statistically significant reduction in } \\
\text { burning sensation }(P=0.008) \text {, improvement in mouth } \\
\text { opening }(P=0.02) \text {, and cheek flexibility }(P=0.01)\end{array}$ \\
\hline $\begin{array}{l}\text { Srivastava et al. } \\
\qquad(2015)^{21}\end{array}$ & $\begin{array}{l}\text { To investigate the clinical efficacy of herbal } \\
\text { medicines for the treatment of OSMF }\end{array}$ & $\begin{array}{l}\text { Topical application of } 1 \mathrm{gm} \text { tulsi and } 1 \mathrm{gm} \text { turmeric } \\
\text { mixed in glycerine base } 3 \text { - } 4 \text { times / day }\end{array}$ & $\begin{array}{l}\text { Mean burning sensation was } 6.07 \pm 1.75 \text { before the } \\
\text { treatment and } 2.22 \pm 1.41 \text { after the treatment } \\
\qquad(\mathrm{P}<0.001) \text {. } \\
\text { Mean mouth opening was } 24.46 \pm 4.0 \mathrm{~mm} \text { before the } \\
\text { treatment and } 27.85 \pm 3.39 \mathrm{~mm} \text { after the treatment }(\mathrm{P}< \\
0.001)\end{array}$ \\
\hline $\begin{array}{l}\text { Nigam et al. } \\
(2017)^{19}\end{array}$ & $\begin{array}{l}\text { To evaluate the efficacy of curcumin in } \\
\text { reducing the burning sensation in potentially } \\
\text { malignant disorders of oral cavity. }\end{array}$ & $\begin{array}{l}\text { Tab Turmix twice daily } 15 \text { days along with the topical } \\
\text { application of turmeric and honey in a paste form by } \\
\text { cotton applicator } 2-3 \text { times daily }\end{array}$ & VAS score decreased from 6.91 to 3.98 after 15 days. \\
\hline $\begin{array}{l}\text { Piyush et al. } \\
(2019)^{11}\end{array}$ & $\begin{array}{l}\text { To evaluate and compare the therapeutic } \\
\text { response of lycopene and curcumin with } \\
\text { placebo in OSMF patients }\end{array}$ & $\begin{array}{l}\text { Lycopene capsules } 8 \mathrm{mg} \text { twice daily } \\
\text { Curcumin tablets } 300 \mathrm{mg} \text { twice daily }\end{array}$ & $\begin{array}{l}\text { Improvement in mouth opening, burning sensation, tongue } \\
\text { protrusion, and cheek flexibility was } 3.9 \pm 4.9 \mathrm{~mm}, 4.8 \pm 2.6 \text {, } \\
5.0 \pm 7.2 \mathrm{~mm}, \& 0.36 \pm 0.71 \mathrm{~mm} \text {, respectively, for curcumin } \\
\text { and } 4.1 \pm 4.2 \mathrm{~mm}, 5.0 \pm 2.3,2.4 \pm 3.5 \mathrm{~mm}, \& 0.66 \pm 0.80 \mathrm{~mm} \text {, } \\
\text { respectively, for lycopene }(\mathrm{P}<0.05) .\end{array}$ \\
\hline $\begin{array}{l}\text { Kushwaha et al. } \\
\qquad(2019)^{15}\end{array}$ & $\begin{array}{l}\text { To evaluate response of atrophic and erosive } \\
\text { OLP to lycopene }\end{array}$ & $\begin{array}{l}\text { Capsule lycopene } 4 \mathrm{mg} \text { / day orally for } 8 \text { consecutive } \\
\text { weeks to } 13 \text { OLP patients }\end{array}$ & Mean Thongprasom clinical sign score reduced by $60 \%$. \\
\hline $\begin{array}{l}\text { Bakhshi M et al. } \\
\qquad(2020)^{22}\end{array}$ & $\begin{array}{l}\text { To evaluate the efficacy of a combination of } 1 \\
\% \text { nanocurcumin gel with } 0.1 \% \\
\text { triamcinolone acetonide mouth rinse for OLP }\end{array}$ & $\begin{array}{l}31 \text { patients with erosive or ulcerative OLP received } 0.1 \\
\% \text { triamcinolone mouth rinse and were then randomly } \\
\text { divided into two groups; Group 1: Combination therapy } \\
\text { with } \% 1 \text { nanocurcumin gel or Group 2: Placebo gel }\end{array}$ & $\begin{array}{l}\text { A significantly higher decrease in the mean REU score was } \\
\text { observed with nanocurcumin }(\mathrm{P}<0.001) \text {. }\end{array}$ \\
\hline
\end{tabular}

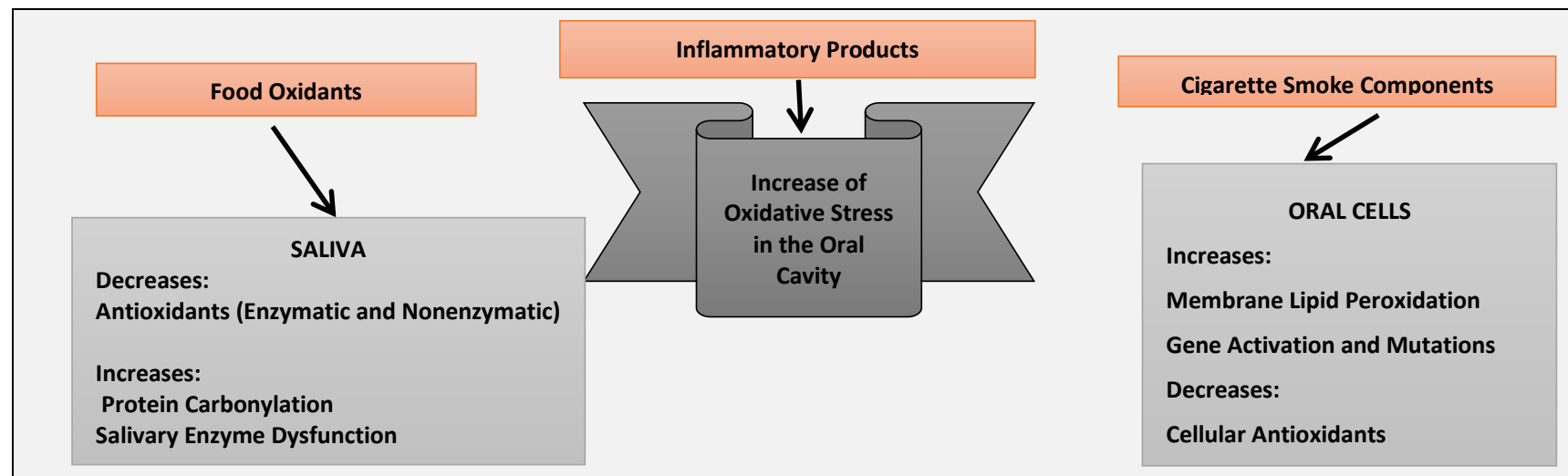

Figure 1. Shows Effect of Increased Oxidative Stress on Saliva and Oral Cells 


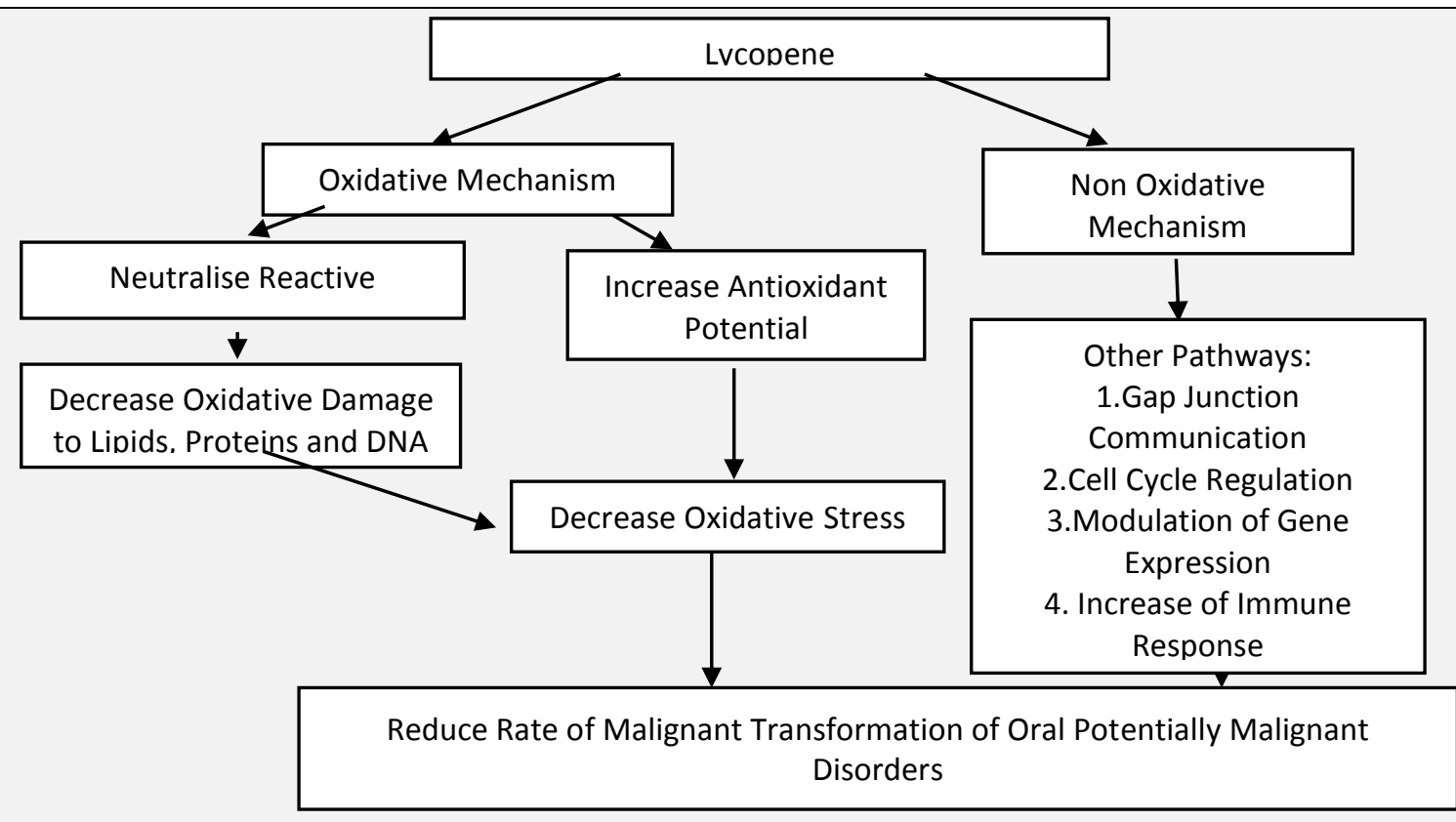

\section{Figure 2. Overview of Mechanism of Action of Lycopene as a Chemo Preventive Agent}
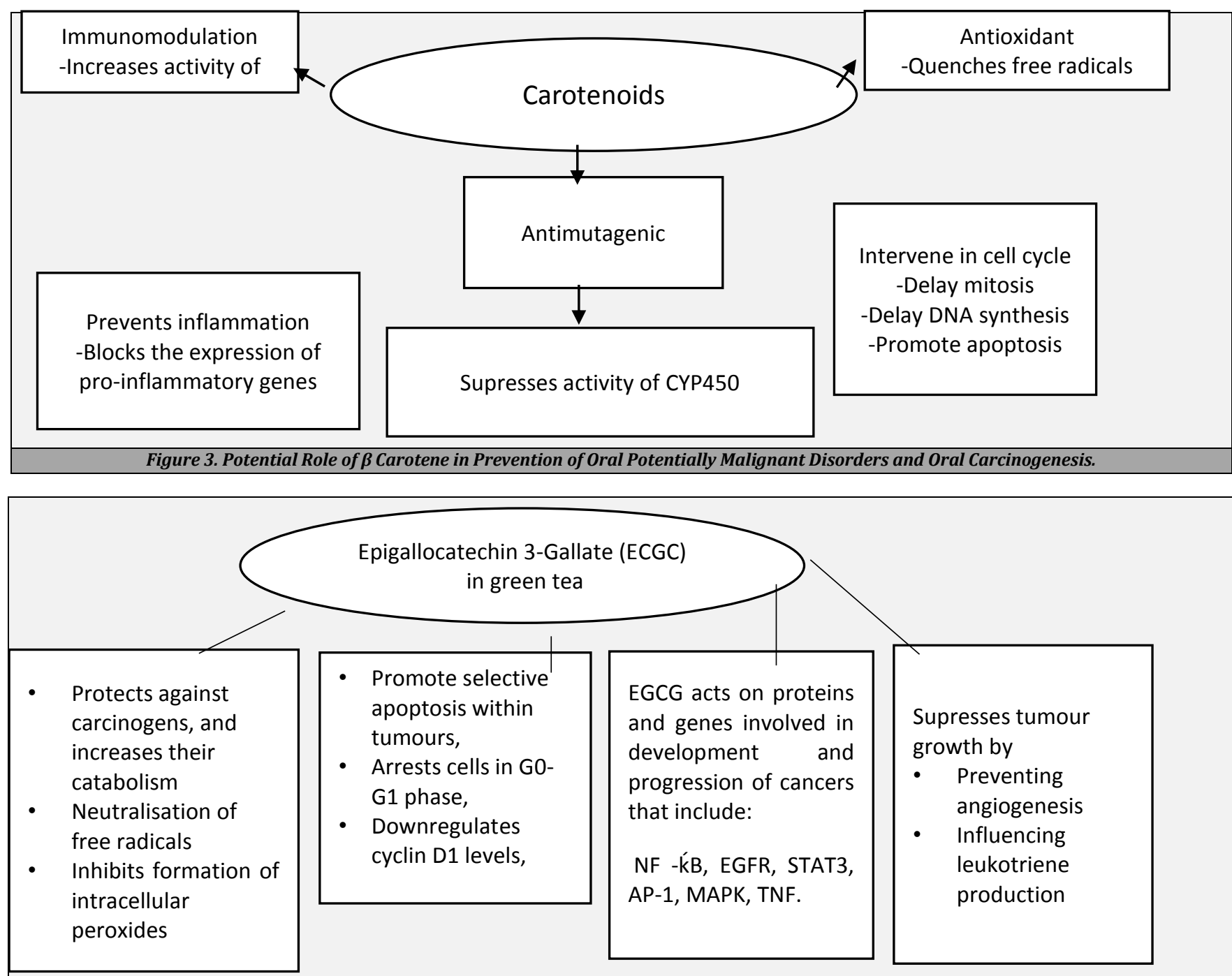

Figure 4. Shows Therapeutic Effects of Active Constituent of Green Tea, i.e. Epigallocatechin 3-Gallate in Chemoprevention 

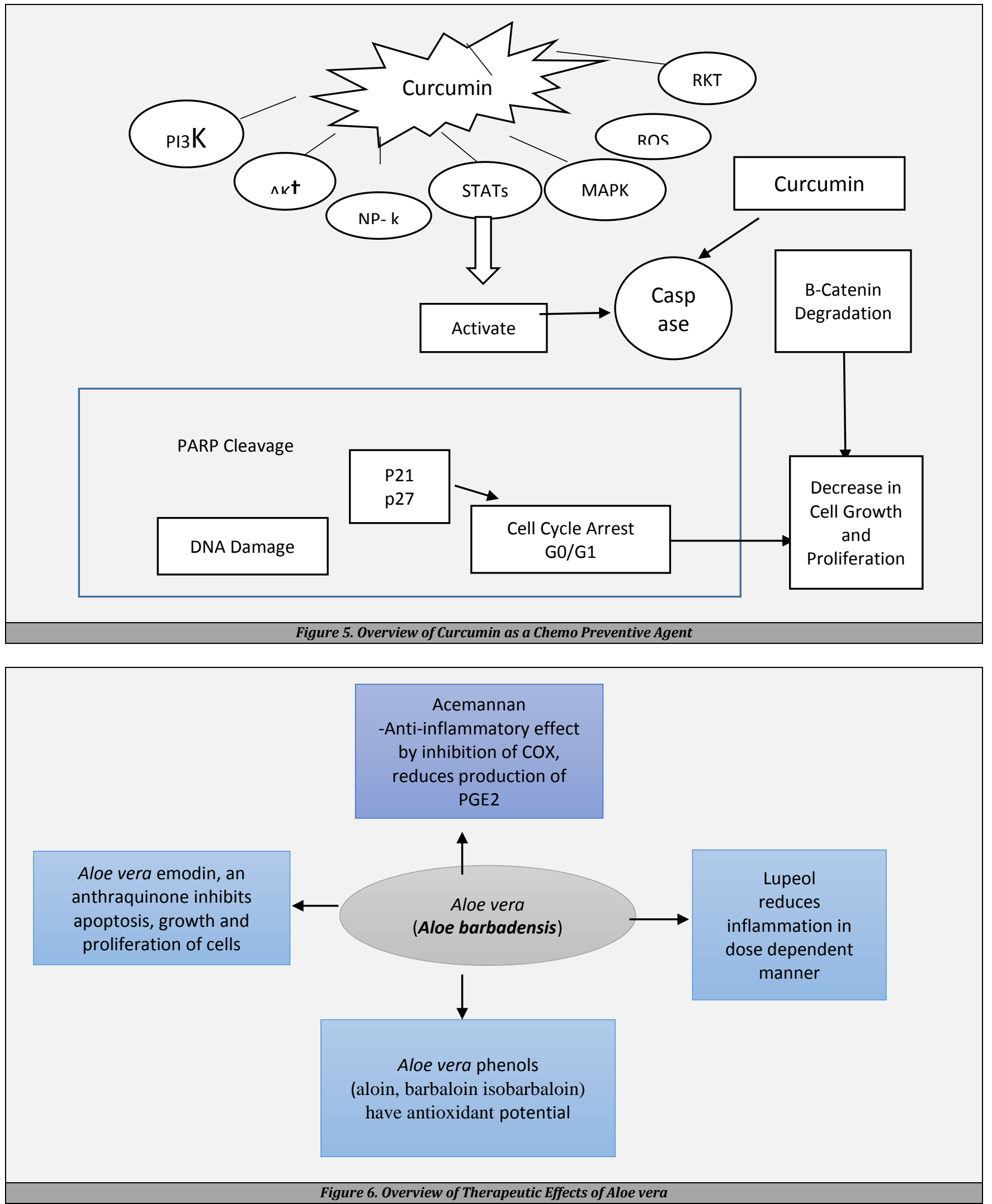

Table 2 illustrates various phytochemical compounds present in natural herbs and their mechanism of action, and Table 3 summarizes preclinical and clinical data from literature pertaining to effectiveness of herbs and their extracts in the treatment of oral PMDs.

\section{MISCELLANEOUS PLANT DERIVED PHYTOCHEMICALS}

\section{Black Tea}

Black tea has high concentration of catechins and the flavins that delay tumourigenesis, induces apoptosis, scavenges ROS and downregulates cyclooxygenase 2 (COX2), NFḱB, protein kinase $\mathrm{B}$ (Akt) and interferes with activity of carcinogen 
metabolizing enzymes. ${ }^{33}$ Debolina et al. ${ }^{34}$ suggested that regular intake of black tea at least above four cups can reduce tobacco associated DNA damage.

\section{Neem}

Neem (Azadirachta indica), contains catechin which can inhibit the production of MMP, thereby reducing the invasion and migration of cancer cells. Its anti-inflammatory potential is explained by suppression of activation of NF-kB which induces apoptosis of cancer cells. 35,36

\section{Tulsi}

Holy Basil, Ocimum sanctum Linn well known as tulsi in India, possess potent anticancer, anti-inflammatory and antioxidant properties. Tulsi due to its immunomodulating property can be used to relieve the symptoms of OLP and other precancerous lesions. Eugenol and linalool have been studied to enhance its antifungal activity against candida albicans and candida tropicalis, hence, could be used as an alternative treatment option for candidiasis. ${ }^{37,38}$ Srivastava et al. ${ }^{21}$ found local application of 1 gram of tulsi in glycerine 4 - 5 times / day for 15 mins resulted in reduction in burning sensation and increase of mouth opening in OSMF patients. In another comparative trial, Singh et al. ${ }^{39}$ found it effective in reducing burning sensation, pain and white striae in OLP patients.

\section{Ginger}

Ginger (Zingiber officinale Roscoe) is well known condiments belonging to zingiberaceae family and consist of numerous active constituents. Gingerol, is a major component that decreases progression of dysplasia in oral PMDs by its unique antioxidant, anti-inflammatory, anti-angiogenesis and anticancer properties. It exerts anti-inflammatory effect by inhibition of arachidonic acid metabolism in both COX and LOX pathways, inhibits LPS induced activation of macrophages by decreasing proinflammatory cytokines and chemokines, decreases proliferation of T cells and release of IL-2 and IFN $\gamma$. Ginger extracts exerts dose dependent cytotoxicity on oral cancer cells by activation of caspase 3 mediated apoptosis, reduces expression of VEGF. 39

\section{Peppermint}

Peppermint (Mentha piperita) is a natural herb belonging to lamiaceae family and has stimulant, carminative properties. It has long history of safe use, both in medicinal preparations and as a flavouring agent. Mentha extract (ME) acts as a potential anticancer agent by induction of cellular apoptosis, up regulation of caspase 3 expression, causes G1 cell cycle arrest, up regulation of bax gene, and elevated expression of p53 and p2 1 induces proinflammatory cytokine response. 4,40

\section{Chamomile}

Chamomile, Matricaria recutita, L., syn. Matricaria chamomilla $\mathrm{L}$ is most ancient medicinal herb, member of Asteraceae family, dried flowers of chamomile contain terpenoids, flavanoids, 1 - $2 \%$ volatile oils such as alpha-bisabolol, alphabisabolol oxides $A \& B$, and matricin, that contribute to its therapeutic benefits. Apigenin, chemical compound of chamomile is gaining interest due to its excellent antimutagenic and anticancer properties. ${ }^{37}$ It regulates cell cycle at all stages; protects DNA from the genotoxic damage, slows down cell cycle progression, induces apoptosis and scavenges free radicals. It exhibits pro apoptotic activity by up regulation of p53 expression, increases expression of Bax and Bak apoptotic protein, caspase 3 and 9 expression, inhibits VEFF, MMP 9 and COX 2 expression thereby play a major role inhibition of tumour angiogenesis and metastasis. It has been found that $2.5 \%$ chamomile infusion resulted in reduction of intensity of chemotherapy induced oral mucositis by decrease of pain score and fewer ulcerations than controls at day 22 after first cycle of chemotherapy. 6,41

\section{Mushrooms}

Mushrooms such as shitake, maitake, reishi and some agaricus species have emerged as a wonderful source of antioxidants. The active components of mushrooms are lentinan, krestin, hispolon, lectin, calcaelin, illudin S, psilocybin, Hericium polysaccharide A and B (HPA and HPB), ganoderic acid, schizophyllan, laccase, etc. Polysaccharides are most potent component of mushroom with anti-tumour and immunomodulating properties. 4,6,42 They enhance tumour cell killing and inhibition of metastasis by increasing number of immunocompetent cells such as macrophages, cytotoxic $\mathrm{T}$ lymphocytes, NK cells and by recruitment of antibodies at the tumour site and prevents the malignant transformation of oral PMDs. ${ }^{42}$

\section{SAFETY OF PHYTOCHEMICALS}

Plant based products, phytochemicals are generally considered safe; side effects have been reported to occur at larger doses or due to presence of certain impurities e.g. allergens, pollens etc. ${ }^{40}$ Unlike allopathic medications, herbal products are not tested for the purity; therefore, physicians should be aware of various drug interactions and patients should take phytochemical supplementation only on physician's prescription.

\section{CONCLUSIONS}

Emerging antimicrobial resistance and side effects which, we are facing time to time with these allopathic medicines recapitulate the need of phytomedicine in the treatment of oral mucosal lesions. Many researchers have found absolute results i.e., clinical improvement in burning sensation, difficulty in swallowing and speech, and reduction in pain associated with the lesion with both topical and systemic formulations of herbs such as aloe vera, turmeric, lycopene, etc. More evidence-based trials should be carried out in future to establish phytochemicals as a reliable adjunctive therapy in the treatment of oral PMDs.

Financial or other competing interests: None.

Disclosure forms provided by the authors are available with the full text of this article at jemds.com. 


\section{REFERENCES}

[1] Shetti N, Patil R. Antioxidants: its beneficial role against health damaging free radical. World Journal of Science Technology 2011;1(11):46-51.

[2] Splieth $\mathrm{CH}$, Sumnig W, Bessel F, et al. Prevalence of oral mucosal lesions in a representative population. Quintessence Int 2007;38(1):23-9.

[3] Carr C, Julia NG, Wigmore T. The side effects of chemotherapeutic agents. Current Anaesthesia and Critical Care 2008;19(2):70-9.

[4] Agrawal N, Gupta ND, Garg AK, et al. Resurgence of phytomedicine use in dentistry. Am J Phytomed Clin Ther 2014;3:322-33.

[5] Nair GR, Naidu GS, Jain S, et al. Clinical effectiveness of aloe vera in the management of oral mucosal diseases-a systematic review. J Clin Diagn Res 2016;10(8):1-10.

[6] Liu RH. Potential synergy of phytochemicals in cancer prevention: mechanism of action. J Nutr 2004;134(Suppl 12):3479S-85S.

[7] Lushchak VI. Free radicals, reactive oxygen species, oxidative stress and its classification. Chem Biol Interact 2014;224C:164-75.

[8] Choudhari SK, Chaudhary M, Gadbail AR, et al. Oxidative and antioxidative mechanisms in oral cancer and precancer: a review. Oral Oncol 2014;50(1):10-8.

[9] Rekha VR, Sunil S, Rathy R. Evaluation of oxidative stress markers in oral lichen planus. J Oral Maxillofac Pathol 2017;21(3):387-93.

[10] Sudarshan R, Annigeri RG, Vijayabala GS. Aloe vera in treatment of oral submucous fibrosis-a preliminary study. J Oral Pathol Med 2012;41(10):755-61.

[11] Piyush P, Mahajan A, Singh K, et al. Comparison of lycopene and curcumin in oral submucous fibrosis: a randomized controlled trial. Oral dis 2018;25(1):73-9.

[12] Lycopene. Monograph. Altern Med Rev 2003;8(3):336-42.

[13] Singh MP, Krishanappa R, Bagewadi A, et al. Efficacy of oral lycopene in the treatment of oral leukoplakia. Oral Oncol 2004;40(6):591-6.

[14] Gowda BB, Yathish TR, Sankappa S, et al. The response of oral submucous fibrosis to lycopene-a carotenoid antioxidant: a clinicopathological study. Journal of Clinical and Diagnostic Research 2011;5(3):882-8.

[15] Kushwaha RP, Rauniar GP, Rimal J. Clinical assessment of the effects of lycopene in the management of oral lichen planus. Int Dent Med J Adv Res 2019;5:1-5.

[16] Rathod YG, Kulkarni SP, Khairnar MR, et al. Estimation of serum beta carotene level in patients suffering from oral submucous fibrosis. J Exp Ther Oncol 2018;12(4):26771.

[17] Garewal HS, Meyskens FL Jr, Killen D, et al. Response of oral leukoplakia to beta-carotene. J Clin Oncol 1990;8(10):1715-20.

[18] Nagpal N, Sood S. Role of curcumin in systemic and oral health. J Natl Sci Biol Med 2013;4(1):3-7.

[19] Nigam N, Enja SPR, Chandra S, et al. Effect of curcumin in reducing burning sensation in potentially malignant disorders of the oral cavity. J Indian Acad Oral Med Radiol 2017;29(1):7-11.
[20] Wang M, Jiang S, Zhou L, et al. Potential mechanisms of action of curcumin for cancer prevention: focus on cellular signaling pathways and miRNAs. Int J Biol Sci 2019;15(6):1200-14.

[21] Srivastava A, Agarwal R, Chaturvedi TP, et al. Clinical evaluation of the role of tulsi and turmeric in the management of oral submucous fibrosis: a pilot, prospective observational study. J Ayurveda Integr Med 2015;6(1):45-9.

[22] Bakhshi M, Gholami S, Mahboubi A, et al. Combination therapy with $1 \%$ nanocurcumin Gel and $0.1 \%$ triamcinolone acetonide mouth rinse for oral lichen planus: a randomized double-blind placebo controlled clinical trial. Dermatol Res Pract 2020;2020:4298193.

[23] Suganuma M, Okabe S, Sueoka N, et al. Green tea and cancer chemoprevention. Mutat Res 1999;428(1-2):33944.

[24] Sazuka M, Isenmura M, Isemura S. Interaction between the carboxyl-terminal heparin-binding domain of fibronectin and(-)-epigallocatechin gallate. Biosci Biotechnol Biochem 1998;62(5):1031-2.

[25] Hsu CH, Tsai TH, Kao YH, et al. Effect of green tea extract on obese women: a randomized, double-blind, placebocontrolled clinical trial. Clin Nutr 2008;27(3):363-70.

[26] Hsu SD, Singh BB, Lewis JB, et al. Chemoprevention of oral cancer by green tea. Gen Dent 2002;50(2):140-6.

[27] Schwartz JL, Baker V, Larios E, et al. Molecular and cellular effects of green tea on oral cells of smokers: a pilot study. Mol Nutr Food Res 2005;49(1):43-51.

[28] Masuda M, Suzui M, Lim JTE, et al. Epigallocatechin-3gallate inhibits activation of HER-2/neu and downstream signaling pathways in human head and neck and breast carcinoma cells. Clin Res Cancer 2003;9(9):3486-91.

[29] Chen D, Wan SB, Yang $H$, et al. EGCG, green tea polyphenols and their synthetic analogs and prodrugs for human cancer prevention and treatment. Adv Clin Chem 2011;53:155-77.

[30] Bhat G, Kudva P, Dodwad V. Aloe vera: natures soothing healer to periodontal disease. J Indian Soc Periodontol 2011;15(3):205-9.

[31] Saini S, Dhiman A, Nanda S. Traditional Indian medicinal plants with potential wound healing activity: a review. Int J Pharm Sci Res 2016;7(5):1809-19.

[32] Ali S, Wahbi W. The efficacy of aloe vera in management of oral lichen planus: a systematic review and metaanalysis. Oral Dis 2017;23(7):913-8.

[33] Halder A, Raychowdhury R, Ghosh A, et al. Black tea (Camellia sinensis) as a chemopreventive agent in oral precancerous lesions. J Environ Pathol Toxicol Oncol 2005;24(2):141-4.

[34] Pal D, Banerjee S, Indra D, et al. Influence of regular black tea consumption on tobacco associated DNA damage and HPV prevalence in human oral mucosa. Asian Pac J Cancer Prev 2007;8(2):263-6.

[35] Lakshmi T, Krishnan V, Rajendran R, et al. Azadirachta indica: a herbal panacea in dentistry-an update. Pharmacogn Rev 2015;9(17):41-4.

[36] Paul R, Prasad M, Sah NK. Anticancer biology of Azadirachta indica L (neem): a mini review. Cancer Biol Ther 2011;12(6):467-76.

[37] Salganik RI. The benefits and hazards of antioxidants: controlling apoptosis and other protective mechanisms in 
cancer patients and the human population. J Am Coll Nutr 2001;20(Suppl 5):464S-72S.

[38] Singh V, Singh G, Pal M, et al. Treatment of lichen planus; a comparative study. J Tradit Med Clin Natur 2017;6(246):2.

[39] Stoner GD. Ginger:is it ready for prime time? Cancer Prev Res (Phila) 2013;6(4):257-62.
[40] Mimica-Dukić N, Bozin B, Soković M, et al. Antimicrobial and antioxidant activities of three mentha species essential oils. Planta Med 2003;69(5):413-9.

[41] Kidd PM. The use of mushroom glucans and proteoglycans in cancer treatment. Altern Med Rev 2000;5(1):4-27.

[42] Eisenberg DM, Kessler RC, Foster C, et al. Unconventional medicine in the United States. Prevalence, costs and patterns of use. N Engl J Med 1993;328(4):246-52. 